\title{
HILL MARI PRONUNCIATION NORMS AS AN IMPORTANT ASPECT FOR PRIMARY AND SECONDARY SCHOOL TEACHERS
}

\author{
Nadezhda M. Krasnova ${ }^{1}$ and Tatiana V. Yantsukova ${ }^{2^{*}}$ \\ ${ }^{1}$ Assist. Prof. Dr., Mari State University, Russian Federation, krasnovanadezhda5@yandex.ru \\ ${ }^{2}$ Assist. Prof. Dr., Mari State University, Russian Federation, stv79@bk.ru \\ ${ }^{*}$ Corresponding author
}

\begin{abstract}
Hill Mari belongs to Finno-Ugric language group. Unfortunately, according to Consolidated Results of the 2010 All-Russian Population Census held in 2013, the Hill Mari language is spoken only by 21,190 people in the Hill Mari region of Mari El Republic.

The article deals with Hill Mari pronunciation norms explained to primary and secondary school teachers. In order to make oneself easily understood while teaching the language teachers must be able to pronounce Hill Mari sounds correctly according to the language norms. Moreover, the teacher must also be able to teach the correct pronunciation. Therefore, one of the main aims of a primary and secondary school teachers is to know all the pronunciation norms which are accepted in the Hill Mari language. In order to achieve this goal a teacher must know what accepted pronunciation is. Hill Mari pronunciation norms are described for the first time in this article.

It is known that correct pronunciation habits in a mother tongue are acquired unconsciously, in our childhood, and as we grow older, our pronunciation habits become more and more fixed. But the situation with the Hill Mari language is quite different because of the huge influence of the Russian language. It is obvious that Russian pronunciation norms influence Hill Mari pronunciation norms. Therefore it is very important to know then especially for primary and secondary school teachers.
\end{abstract}

Keywords: Hill Mari, Pronunciation Norms, Consonants, Vowels.

\section{INTRODUCTION}

Every literary language has spelling and pronunciation norms. If the pronunciation norms are not fixed in the language, then they can change over time or completely disappear. Therefore, in any language, much attention is paid to determining the norms of pronunciation and stress. Therefore it is very important for Hill Mari language teachers to be aware of the language norms.

Pronunciation norms of the Hill Mari language are determined by phonetic laws as concatenation of words, palatal harmony, border signal at the junction of morphemes and by phonetic processes which include the loss of sounds or syllables, the insertion of an extra sound into the word and at the beginning of the word, rearrangement of sounds, assimilation and dissimilation of sounds, alternation of sounds.

Pronouncing, or orthoepic, norms of the Hill Mari language include the rules for the pronunciation of vowels 
and consonants, the rules for the pronunciation of combinations of consonants, the rules for the pronunciation of suffixes and particles, the rules for the pronunciation of individual grammatical forms, and the peculiarities of the pronunciation of borrowed words.

\section{PRONUNCIATION OF VOWELS}

The sounds indicated by the letters $a, \ddot{a}, o, \ddot{o}, u, \ddot{u}, s, \partial, i, e$ both in a stressed and unstressed position are pronounced in accordance with the spelling: avaha 'husk', akshaklash 'limp', ävä ' mother ', äshb̈indääräsh' to remember ', oroly 'watchman', onton (Onton) 'Anton', öräsh 'to be surprised', urat 'tact', urdash 'to keep', pulysh 'shoulder', üdäsh 'sow', 'ikty' 'one', imnin 'on a horse', knigäet' your book ', ekhel' 'acorn', püergy 'man'.

After the front vowels ä, $\ddot{b}, \ddot{o}, \ddot{u}, i$, e, the front vowels ä, $\ddot{b}, \ddot{o}$, ü are pronounced according to the law of palatal harmony: tsäshän 'happy', b̈́düır 'girl', öräsh 'to be surprised', ÿzhäsh' to invite' , käpb̈ishtb̈l 'on the body', imnid̈̈ı̈̈̈ 'horseless', kogoeshnäsh ‘to be proud', püerg̈̈ 'man', kelesäläsh 'suggest', kelesäsh 'say', irb̈kän 'free'.

Borrowed from the Russian language (or through the Russian language) [ы] is pronounced in the same way as in Russian: sýr 'cheese', kosýnka 'kerchief ', rýnok 'market', kavýchka ' quotation mark ', privýchka 'habbit'.

If two identical vowels are written in a word, then a long vowel sound is not pronounced in the word, but both vowel sounds are pronounced in two separate syllables: olmaan [olmá/án], karkaan [karká/án], kamakaan, altatsaan [altatsá/án], knigään [knigä/ä́n], kletkään, süınzään [süıncä/ấn].

The letters e, yu, ya at the beginning of the word and after the vowel are pronounced as two sounds: ezhӹng [yézhӹrk] 'joint', embyl [yemmpöl] 'nastrug', saraesh [sarayesh] 'in the stable', vuesh [vuyesh] 'on the head ', kaesh [kayesh] 'is isible ', yugata [yugata] 'cool', yuran [yúran] 'rainy', yazho [yazho] 'good', yadyshtash [yadyshtash] 'ask'.

The letters yu, ya after the $ъ$ (solid sign) are pronounced as two sounds: akyary [a'yary] 'unsuitable', neryuk [neryuk] 'snoring', omyua [omyua] 'sleepy'.

\section{PRONUNCIATION OF CONSONANTS}

In syllables with front vowels ä, $\ddot{b}, 0 \ddot{0}, \ddot{u}, i$, e consonants are pronounced with a slight softening: äk 'price', tsäsh 'happiness', näläsh 'to take', siräsh 'to write', b̈düiräsh 'a girl', ölväl 'an underground', örkb̈ 'lazy', órb̈lktäsh 'to surprise', üp 'hair', shündülk 'chest', etc.

Before the letter $e$ the consonant is pronounced with a slight softening: kelesh 'is need', mel 'a chest', nélb̈ 'heavy', ner 'a nose', teve 'this', peliash 'semi-annual', selmä 'frying pan', shel 'fat'.

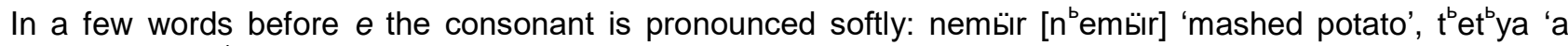
child' (the sign ' ${ }^{b}$ indicates the softness of the consonant).

Before the letter я (ya) a soft consonant is pronounced: manyáry [manbyáry] 'how much', semnya [semnьä] 'family', totya [t'yot'ya] 'grandfather', tyapa [t'yapa] 'leg'.

The letter $d$ at the end of the word is pronounced like an unvoiced sound [t]: lyd [lyt] 'read', kid [kit] 'hand', kud [kut] 'six', pad [pat] 'a boiler'.

The letter $ж(z h)$ at the end of the word is pronounced as the sound [zh]: vb̈itskb̈izh [vb̈itskb̈izh] 'thin', kozh [kozh] 'a fur', kurnyzh [kurnyzh] 'a black raven', nuzh [nuzh] 'nettle', b̈rvb̈lzh [ǘrvb̈̈h] 'a fox'.

The letter $z$ after the letter $n$ is pronounced as [ts]: mynzash [myntsash] 'carry eggs', pynzalash [pyntsalash] 'to wring out ', sanzal [santsal] 'salt ', süinzä [süíntsä] 'eyes', shüinzäsh [shüintsäsh] 'sit '.

The letter $ж(z h)$ after letters $n, n$ ', $m$ is pronounced as [ch]: anzhash [anchash] 'to look', anzhy [anchy] 'look', vanzhak [vanchak] 'bridge', vanzhyshty [vanchyshty] 'let them pass', mӹızhӹ [mӹ́nchӹ] 'and me', ẗ̈ınzhӹ

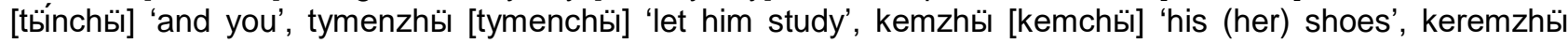
[keremmchü] 'his (her) rope', tängemzhb̈ [tängkemzḧ̈] 'my friend'.

The letter $\boldsymbol{w}(\mathbf{s h})$ after the letter $t$ is pronounced as [ch]: myretshb̈ [myretch ̈]] 'your song', närätshb̈

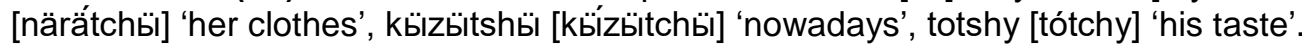

The distinctive sound in the Hill Mari language glottal stop [?] is denoted by the letters k, t, d: ak li [a? li] 'not allowed', vadny [vá?ny] 'in the evening', maklaka [ma?laka] 'lump', kaklyaka [kalaka] 'crooked', totly [to?ly] 
'tasty', karakna [kara?na] 'our raven', komdyk ner [komdy?_ner] 'snub-nosed', kokly [ko?ly] 'twenty', utla [u?la] 'too' , tsaklash [tsa?lash] 'notice', yaklaka [ya?laka] 'slippery'.

\section{PRONUNCIATION OF CONSONANT COMBINATIONS}

The combination of sounds $H(\eta)$ in the middle of a word is pronounced as a complex sound [nk]: yongy [yónky] 'space', yӹng̈̈l [yӹínk̈̈l] 'bell', karangdash [karanktash] 'move away', mongyr [monkyr] 'body 'on the contrary', pongy [ponky] 'mushroom', tüngäläsh [ẗ̈nkäläsh] 'to start', tengechü [tenkéchü] 'yesterday', shongy [shonky] 'old', shongeshtäsh [shonkéshtäsh] 'to froth'. It should be noted that $H(\eta)$ is a sonorous nasal consonant. There is no special letter for this sound in the Hill Mari alphabet.

At the end of the word, the combination of sounds $n g$ is pronounced as [n]: karang [karan] 'move away', tong [ton] 'seed', yäng yila [yän_jyla] 'enviously', karang keäsh [karan_keääsh] 'move away', pyrtsong puash [pyrtson_puash] 'to knock', täng liäsh [tän_liäsh] 'to be a friend', püll̈̈shtb̈ing yakte [pülb̈íshtb̈in_yakte] 'from ear to ear'.

The letter combination of letters жu (zhsh) is pronounced as a long sound [ $\overline{s h}]$ : kozhshy [kóshy] 'his spruce',

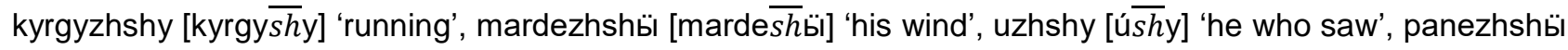
[pan'esh ̈̈] 'burning'.

In combinations of letters штш (shtsh), штм (shtm) the sound [t] is not pronounced: kashtshy [kashy] 'walked', kashtshyla [kashyla] 'passing', kashtmyky [kashmyky] 'passing', kashtmyla [kashmyla] 'must walk', kashtmeshkӹ [kashmeshk̈̈] 'before walking'; väreshtshӹ [värésḧ̈] 'caught', väreshtmükb̈ [väréshmb̈kӹ] 'hitting'.

If double letters I are used in a word, the consonant $I$ is not pronounced as a long sound, the consonants I will be in two different syllables: yällän [yäl-län] 'alien', kollan [kol-lan] 'fish', coral-lan ( koral-lan) 'coral', küllän [kb̈ll-län] 'for a bolt', püllän [püll-län] 'for a cloud', shkollan [shkol-lan] 'for school'.

If there are double letters $n, m$, they are pronounced as a long sound: iziemmӹ [iziém̄̈] 'decreasing', kelgemmӹ [kelgém̈̈], lydmylanna [lydmylan̄a] 'to our reading'; mälännä [mälänä] 'for us', solalanna [solalan̄a] 'to our village', tymenmülännä [tymenьmb̈länä] 'for our studies'.

\section{PRONUNCIATION OF SUFFIXES AND PARTICLES}

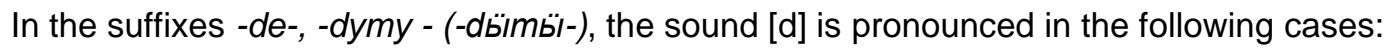

a) in the nominal parts of speech and in the participle before the suffixes -de-, -dymy- (-dümü-) vowels are not omitted: imnide [imn'ide] 'without a horse', kogode [kogode] 'without an adult', lude [lude] 'without a bone', kymshyde [kymshyde]' without a third', paidade [paidade] 'without wealth', pude [púde]' without firewood', sotyde [sotyde]' without light, töld̈̈lde [töíd̈̈lde] 'without him', tehen̈̈lde [ tekhenь̈̈lde] 'without such', shüdb̈lde [shÿd̈̈lde] 'without a hundred', yngylyshyde [ynkýlyshyde] 'without understanding',

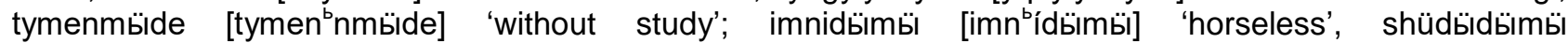
[shÿdüdb̈̈m̈̈]'without a hundred'.

b) when consonants [zh], [z], [j], [l], [r] are used in the nominal parts of speech and participles before the suffixes -de-, -dymy- (-d̈̈̈m̈̈-): vazde [vazhde] 'without a root ', vuyde [vujde] 'without a head', kozhde [kozhde]' without a fir', kolde [kolde] 'without fish', saraide [saraide] 'without a barn', porde [porde] 'without a piece of chalk', vazhmy [vazhdimy] 'without a root', kozhdymy [kozhdymy] 'without a fir', vuydymy [vuidymy]

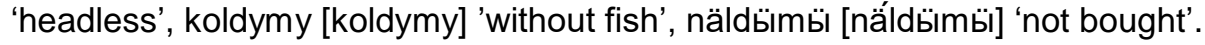

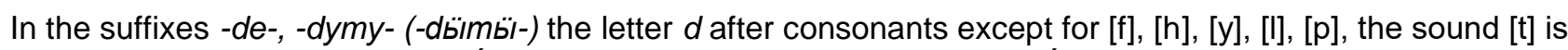
pronounced: kürpüitsde [kürpüitste] ' without a brick ', küchde [kb̈ichte] 'without a nail', mizhgemde [mizhgemte] 'without boots', pyndé [pynte] 'without feathers', samynıde [samyn te] 'without errors', classde [claste] 'without a class', tängemde [tắnkemte] 'without my friend', pyshde [pýshte] 'without a boat';

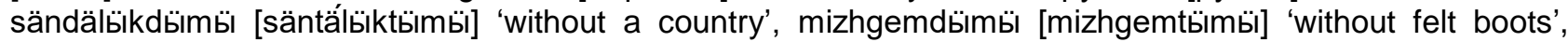
pyndym [pýntymy] 'without feathers'.

When the suffix -de- is attached to a word ending in the sound [t], a long sound $[\bar{t}]$ is pronounced: kidde [kite] 'without a hand', tängetde [täne $\bar{t} \mathrm{e}]$ 'without your friend', kashtde [kash $\bar{t}$ ] ' 'did not go', b̈shtältb̈̈de [̈̈shtä́l $\bar{t}$ ] 'not done'.

When the suffix -de- is attached to a verb or a gerundial form of a verb, in the suffix -de-after the vowels $y, \ddot{b}$ the sound [d] is pronounced: anzhyde [anchyde] 'not looking', myryde [mýryde] 'did not sing', pyryde 
[pýryde]' did not enter ', pütẗ̈lde [püïẗ̈de]' did not end ', b̈shtb̈lde [üshtb̈lde] 'did not do'.

In verbs and participles, after all vowels (except for $\ddot{\mathrm{b}}, \ddot{\mathrm{i}}$ ) and after all consonants in the -de- suffix the sound [t] is pronounced: kede [kéte] 'did not go away', kide [kite] 'did not lie', kode [kote] 'did not weave', pude (from the verb puash 'to give') [pute] 'did not give', where (about the verb küäsh 'to cook') [küte] 'did not cook', vylgyzhde [vylgýshte] 'did not flutter', vatsde [vátste] 'did not go to bed', kaide [kaite] 'could not be seen', kyralde [kyralte] 'did not plow', mande [mante] 'did not say', chüchde [chüchte] 'did not close', kushde [kúshte] 'did not increased'.

In the suffix -ge- after vowels and consonants [y], [l], [p], [f], [h], the sound [g] is pronounced: izige-kogoge [izigé-kogogé] 'and young, and old', tomage [tomagé ] 'together with the house', solage [solagé] 'together with the village', saraige [saraigé] 'together with the barn', payge [paygé] 'together with meat', tylge [tylgé] 'with fire', nyrge [nyrge] 'together with the field', vazge [vazgé] 'together with the root', myzge [myzgé] 'slowly'.

In the suffix -ge- after the rest of the consonants in the suffix -ge- the letter $g$ is pronounced as [k]: säränge [säränké] 'together with a glade', tängge [tänké] 'together with a friend', pörtge [pörtké] 'together with a house', padge [patké] 'together with a cauldron', kidge [kitke] 'with the hand'.

In the suffixes -vlä-, -lyk- and in the particle -ok there is no palatal harmony: in the suffix -vlä- [ä] is always pronounced, in the suffix -lyk- [ы] is pronounced, in the particle - ok [0] is pronounced: kombyvlä 'geese', cornyvb̈l 'roads', lashtykvlä 'pieces', tumvlä 'oaks', shanymashvlä 'thoughts', b̈düirvlä 'girls'; kurymashlyk 'forever', päshälyk 'for work', sünzälyk 'glasses', tygyrlyk 'for a shirt', ̈̈l̈̈ishä́shlyk 'must live', kelesb̈ishäshlyk 'must say'; isiok 'and (even) small', tumok 'and (even) oak'.

\section{CONCLUSION}

In modern Hill Mari pronunciation, two tendencies are currently observed: classical norms and nonobservance (or ignorance) of norms, pronunciation according to spelling rules.

Our material shows that sounds, combinations of sounds are pronounced correctly by people of the older generation, as well as by young people (25-35 years old), who are trying to preserve the classical norms of pronunciation. According to our research, children and young people (especially schoolchildren) pronounce words in accordance with the spelling rules, that is, as it is written. We believe that the lack of an pronouncing dictionary of the Hill Mari language, which has not been used in the educational process in general education schools until now, led to this.

It is necessary to introduce the study of orthoepy norms of the Hill Mari language into the plan of the subject "Hill Mari language".

\section{ACKNOWLEDGEMENT}

This research was financially supported by the Russian Foundation of Basic Research (Grant NO. 20-01200481 A).

\section{REFERENCE LIST}

Vasikova, L. P. (1994). Kyryk Mary Orfografi Lymder. Yoshkar-Ola. "Mary Elyn periodika" izdatelstvo.

Vasikova, L. P. (1997). Kyryk Mary Yylmyshty Foneticheskiy Processvla. Y Sem, № 1 pp. 134-142.

Nadezhda M. Krasnova, Galina A. Ertsikova (2021). Hill Mari Orthoepy: Concept, Rules and the Importance for Future Teachers of the Hill Mari Language // Proceedings of ADVED 2021- 7th International Conference on Advances in Education. pp. 227-230. 